\title{
Biodiversity as the Basis for Sustainable Development of Mountain Areas
}

\author{
On the Example of North-East Caucaus
}

\author{
Zaburaeva H. Sh. \\ Department of Geology, geophysics, and geo-ecology \\ Kh. Ibragimov Complex Institute of the Russian Academy \\ of Science \\ Grozniy, Russia \\ Oil and Gas Institute \\ Grozniy State Technological Oil University named after \\ M.D. Millionshikov \\ Grozniy, Russia \\ eveggne@mail.ru \\ Zaburaev Ch. Sh. \\ Dispatcher Service of Network operation center SC \\ "Chechenenergo" \\ Grozniy, Russia \\ zaburaev_87@mail.ru
}

\author{
Daukaev As. A. \\ Department of Geology, geophysics, and geo-ecology \\ Kh. Ibragimov Complex Institute of the Russian Academy \\ Earth Science Department \\ Chechen Republic Academy of Science \\ Grozniy, Russia \\ daykaev@mail.ru
}

\begin{abstract}
The article discloses an increasing role of biodiversity in strategies of sustainable development of mountain areas. Unique character and attractiveness of mountain ecosystems due to significant biological, landscape and ethno genetic diversity and their sensibility to anthropogenic have been discussed. Estimation is given to biodiversity of North-East Caucasus based on Red Book List of animals and plants, significantly differentiated by regions and landscape zones. The greatest number of animals listed in the Red Book of North-East Caucasus is in Dagestan and Chechnya. Maximum biodiversity is found in mountain-forest and mountain-meadow zones, and minimal diversity is in the most developed inundable, low land and marine low-land landscapes.
\end{abstract}

Keywords - biodiversity, sustainable development, dynamism, mountain areas, antropogenous factor, conservation areas, network

\section{INTRODUCTION}

The concept "biodiversity" has a dual interpretation: in the wide and narrow meaning. In the first meaning it describes the number, diversity and variability of living organisms, and in the second case it means variety of parameters and biogeosphere. Biodiversity is a foundation of functioning and sustainability of any natural systems: from local to global, i.e. biosphere in general.

New empiric studies prove that biodiversity reduction (micro organisms, fungus and mushrooms, plants and animals) results in loss of ecosystem balance [2, 17, 24, 28]. Contemporary issues which are studied by geo ecologists, climatologists and other researchers: climate global changes, ecological crisis are results of changes in ecosystem functions due to biodiversity reduction and transformation. In 1987 the 7 World wide UN Panel on the Environment and Development made a conclusion that "the humanity can make the development steady" [12]. Due to specific features of mountain geo systems the issue of their sustainable development is more complex and versatile. Most highlands are significantly behind the flat lands in social and economical development [1].

In 1992 mountain regions and people became the World community focus of interest at the First UN Conference on the Environment and Development in Rio de Janeiro. In XXI century agenda the issue of sustainable development of the mountain regions was given a special attention to. Its introduction runs that mountains are a source of water, power, and biodiversity, and the chapter "Accumulation and knowledge enrichment on ecology and sustainable development of mountain areas" stresses high degree of mountains sensibility to ecological disbalance due to anthropogenic factor or nature processes.

The importance of mountains areas sustainable development grounded by the Worldwide mountains area summit in Bishkek in 2002 was acknowledged by the UN. Its geopolitical and geostrategic importance is that it has attracted attention of the international community to the complex problems of the mountain areas. According to chapter 27 of UN Resolution "Estimating ecosystems of the millennium" (2005) mountain area population face such challenges as severe climate conditions; sensitivity of mountain ecosystems to natural and man-made impacts; low agricultural productivity; higher material, technical and energy costs for life support; isolation and others. In Dagestan, in one of the biggest 
mountain areas in Russia in order to attract attention to the problems of mountain areas and for providing conditions for their sustainable development year 2016 was called "the Year of Mountains".

The significance of the mountainology for solving global and regional ecological problems of the humanity can not be overestimated, as about $50 \%$ of the total Earth area is $500 \mathrm{~m}$ above the sea level, $27 \%$ is above $1000 \mathrm{~m}$, and $11 \%$ is above $2000 \mathrm{~m} .12 \%$ of the world population live in the mountain areas and more than a half uses its rich natural resources [5].

Accourding to UNEP classification Russia is a highland country; more than $50 \%$ of the territory is mountains, highlands and uplands. The number of people living in these areas is from 4.2 to $6-7 \mathrm{ml}$ people [1]. Especially diverse are ecosystems, ethno cultural and of historical conditions in Caucasus mountain regions. Mountain ecosystems have preserved significant biological and mineral diversity for millions of years; they are the places of distribution of some original ethnoses (table. 1).

In national biodiversity conservation strategy of Russia it has been noted: "Mountain ecosystems have a unique role in preserving biodiversity in general. Mountain biota has higher tempos of evolution and higher rate of species formation" [11].

Most UNESCO World natural heritage sites, historical complexes are in mountain regions of Altai, Caucasus, Kamchatka and others. Mountain areas differ from flat lands in outer geomorphologic features, increased sensitivity and sensibility to man-made impact, but in deep structure tectonics, magmatic features, extremely dangerous processes (volcanic eruptions, earthquakes, avalanches, mudflows, landslides and other), which influence geo ecological situation and people's living condition.

TABLE I. RELATION OF RUSSIA MOUNTAIN REGIONS ACOORDING TO THEIR MOUNTAINOUSNESS [5]

\begin{tabular}{|c|l|c|}
\hline No & \multicolumn{1}{|c|}{ Regions } & $\begin{array}{c}\text { Mountainous } \\
\text { ness, \% }\end{array}$ \\
\hline 1 & $\begin{array}{l}\text { Adygeya, Dagestan, Ingushetia, Chechnia; } \\
\text { Krasnodarsk, Perm Territories; Sverdlovsk } \\
\text { region; Taimyr Autonomous Area }\end{array}$ & $25-50$ \\
\hline 2 & $\begin{array}{l}\text { Bashkortostan, Kabardino-Balkaria, Sakha } \\
\text { (Yakutia); Krasnoyarsk Territory; Amursk, } \\
\text { Murmansk, Sakhalin, Chelyabinsk regions; } \\
\text { Aginsk and Ust-Ordynsk autonomous areas }\end{array}$ & $50-75$ \\
\hline 3 & $\begin{array}{l}\text { Altai, Buryatia, Tyva, Khakassia, Karachai- } \\
\text { Cherkessia, North Osetia-Allania; Primorsk and } \\
\text { Khabarovskiy Territories; Irkutsk, Kamchatsk, } \\
\text { Kemerovo, Magadan and Chita regions; } \\
\text { Koryaksk, Chukotsk and Evenki Autonomous } \\
\text { Areas }\end{array}$ & More than 75 \\
\hline
\end{tabular}

The concept "sustainable development" has many definitions, according to the aspects of issue (economical, ecological, biological and others) [3, 5, 18 and others]. The most attention is paid to the concept "geo system stability". Many researchers consider Russian variant of the concept "postoyannoe razvitie" not very good, citing B. Shaw: "Changeability is constant but the death is steady" considering the words "constant" and "development" contradictory, development itself can not be steady.

As sustainable (balanced) development of mountain geo systems we should understand the development when their integrity is not influenced, providing rational balance between utilization, protection and reproduction of natural resources production [18].

\section{METHODS AND MATERIALS}

The theoretical and methodological grounds for the research have been the works of V.N. Bolshakov (1988; 2009; 2015), K.I. Berdugin (2009), A.A. Tishkova and Ye.A. Belonovskaya (2014; 2018), A. Waldron, J.A. Tobias (2017), N.G. Yoccoz, K.E. Ellingsen (2018) and others. Reference materials on especially protected Russian and world territories, on UNESCO World natural heritage sites, regional Red Books, where rare extincting animals and plants of Dagestan, Chechen and Ingushetia Republics are listed were used. Methods of comparative analysis, statistic, and content-analysis of the published sources were used.

\section{STEADINESS OF NATURAL ECOSYSTEMS}

Balanced functioning of living organisms of all types provides dynamic stability of natural systems. Anthropogenic activity destroys bionic regulation mechanisms in local ecosystems that influences processes in global ecosystem. Disbalanced ecosystems and anthropogenic bio systems not only support balanced environment but are powerful destabilizers.

With the account of contemporary reality for supporting favorable (comfort) environment for human life and activity it is necessary to preserve natural eco systems and revitalization of transformed ones. Anthropocentric approach to the development of civilization conditions changes in species composition, natural distribution of energy flows in ecological communities, species genetic codes during genetic selection. This explains disability of the disbalanced ecosystems regulate viability of natural ecosystems in local and global scale. Environmental interventions, do not destroying it, are compensated with natural biota (assimilative capacity). Anthropogenic impact influences biodiversity, productivity and stability of Earth ecosystems [28].

At seemingly higher productivity of affected ecosystems (crop lands, grass lands), their disability to support biodiversity at a sufficient level is not doubted. Due to extensive nature exploitation many species are extincting [6].

Negative tendencies in biodiversity reduction continue and acquire global scales, threatening ecosystems ability to provide necessary services and functions (biomass production, pollination) [28]. For example, reduction of tropical and temperate forests can destroy ecological safety of the whole Earth. Forest cutting down is also a matter of concern. Annually about $15 \mathrm{ml}$ ha of the tropical rainforest with the most biodiversity is lost [22]. These forests produce 2-3 times more biomass in comparison with temperate forests. Besides 
consuming "green-house gases", they are habitat for many species of plants and animals. Using lands for cropping and building in 90-ieth of XX century resulted in significant reduction of forests in such countries as Brazil, Russia (Far East), Indonesia and Malazia [22]. These processes lead to land degradation (erosion, desertification and other).

Certainly, in regional and local scales biodiversity reduction has its shade without clear tendency in timely aspects. For example, in tropical freshwater ecosystems this tendencies differ even between taxonomic units (fish, invertebrate, diatomic algae) [25].

The research [27] elicited the fact of land ecosystems biodiversity below "safety limit" due to land use for agrarian purposes. As variation indicator of species number a "biodiversity integrity index" has been suggested (BII). BII reduction by $10 \%$ is permissible.

Loss of biodiversity on the global scale, if no actions are taken, can destroy efforts on sustainable development; result in ecosystems ability to provide services. Ecosystem components are an important component of nature capital. They can be production, environment-forming, informative, and recreational [26]. Climate forming services of ecosystems have global significance. Russia has the world largest massifs of natural ecosystems, with key significance for preserving global biodiversity and supporting biosphere regulation. Carbon runoff rate into Russia forests varies greatly (from 100 to 800 $\mathrm{MtS} /$ year). The greatest carbon sequestration forests have (691.9 MtS/year) which is conditioned by their contemporary predominance and state [26].Nowadays, Russia canopy cover mostly consists of secondary forest growth at different quiescent stage. Significant carbon sequestration is done by swamps (53,4 MtS/year) and fallows (41,6 MtS/year).

A significant role on the global scale has constant mountain ecosystems functioning as deposits of biodiversity [13]. Mountain ecosystem services can not be underestimated [23]. Wild World Fund researches (WWF) evidence global Caucuses conservation value. It is in the list of 200 eco regions with high level of bio diversity on the global scale ("The Global 200" program) [14]. The South-East part of the Caucuses is not an exception. Natural complexes diversity here (due to climatic zoning) has wide ranges - from semidesertic in the North to nival in the South. Consequently, physic-chemical parameters of the environment are different (temperature, humidity, atmospheric pressure, solar radiation and so on). Diversity of soil-climate and geo morphological conditions underlies high biological diversity.

Comparing with other regions Caucuses has always been in the center of researches' attention. The biggest expeditions were organized in XVIII by S.G. Gmelin (1744-1774) and I.A. Guldenshtedt (1745-1781) [13]. The data of this and consequent Caucuses research evidence significant biodiversity of the North-East Caucuses regions under investigation [5, 7 and other]. It is admitted that the issues of nature and biodiversity studies have been underestimated.

\section{BIODIVERSITY INDEXES}

Red Book species, according to Ye.A. Belonovskaya and A.A. Tishkov [7], are indicators of area good condition. Necessity to publish Red Books is caused by anthropogenic impact on the environment on the regional and global scale. They allow attracting attention to biodiversity impoverishment of population on the large scale. In Russia, Red Books are a significant way of preserving biodiversity on the large scale including rare, extincting species of mushrooms, plants and animals [6]. Red Books reflect biodiversity exploration degree of regional ecosystems, population dynamics, its fluctuations and reasons for area decrease.

In Chechnya, Ingushetia, Dagestan plant life there are 2200, 1531 and more than 4500 species correspondingly [8-10]. Herewith, Chechnya and Ingushetia plant life is less studied than Dagestan plant life. It includes unknown and unrecorded species according to the latest data. So, there are about 2600 2700 plant species on the Chechnya territory, among which only 2200 are recorded [10]. Endemic plants number is about 15 , but according to Chechnya botanists calculations their number is about 60. The same situation is in Ingushetia [9]. There are a lot of species in Chechnya, Ingushetia, Dagestan plant life which need protection. The Red Books of Chechnya Ingushetia, Dagestan Republics list more than 150, 89 and 176 plant species correspondingly (Table. 2).

TABLE II. PLANT SPECIES LISTED IN THE RED BOOKS OF THE NORTHEAST CAUCAUSUS REGIONS

\begin{tabular}{|c|c|c|c|c|c|c|c|}
\hline \multirow[b]{2}{*}{ No } & \multirow[b]{2}{*}{ Region } & \multicolumn{6}{|c|}{ Divisions (number of species) } \\
\hline & & 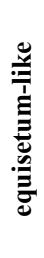 & 尝 & 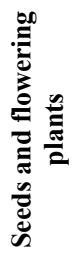 & 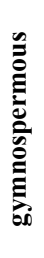 & $\frac{e_{0}^{0}}{\frac{a}{0}}$ & 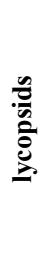 \\
\hline 1 & Chechnya & 1 & 7 & 145 & 5 & - & - \\
\hline 2 & Ingushetia & - & 5 & 81 & 1 & 1 & 1 \\
\hline 3 & Dagestan & - & 8 & 165 & 3 & - & - \\
\hline
\end{tabular}

The Red Books of North-East Caucasus do not include understudied plants (fungus, mushrooms, lichen, moss, club moss). Species listed in the Red Books of the three republics are: yew (Taxus baccata), snow drop narrow-leaved (Galantus angustifolius), Fritillaria caucasica, birch Radde (Betula raddeana) and others. There are Caucasus endemic species (Hymenocystis fragilis, Rhododendron caucasicum) and narrow area endemic plants (Dagestan spleenwort (Asplenium daghestanicum Christ), Psephellus pseudoandinus, Festuca inguschetica).

North-East Caucasus plant life is very diverse. There a lot of natural zones here: semidesertic, steep, forest-steep, marine terraces, mountain-forest, mountain-meadow and nival. Every zone has its peculiar environment, species diversity (including endema), except nival, nearly without plant life.

The wild life in North-East Caucasus is very diverse, both in species and ecological groups which is conditioned by unique 
natural landscape and geographic position of North-East Caucasus territories on the animals' migration routes from Europe, Asia, and Near East. Comparing with the wild life of the USSR, Chechnya has $21.8 \%$ of amphibians ( 8 species), reptiles $-20 \%$ (almost 280 species). Among mammals (about 91 species), $43 \%$ kinds of artiodactyls, $44 \%$ carnivore, up to $25 \%$ of rodents [10]. Local ichthyofauna comes second to only Dagestan by biodiversity, which is a costal republic. Reptiles are represented by three types: lizards, snakes and tortoises. Not less than 17-18 their species penetrate the mountain region as far as Alpine belt. The Chechen Red Book lists 74 kinds of invertebrates (including 1 kind of crustaceous and 73 kinds of insects) and 115 kinds of vertebrates (1 kind of cyclostomatous, 13 of fish, 4 kinds of amphibious, 16 reptiles, 55 of birds and 26 mammals) (Table 3).

TABLE III. SPECIES LISTED IN RED BOOKS OF NORTH-EAST CAUCASUS REGIONS

\begin{tabular}{|c|c|c|c|c|c|c|c|c|c|}
\hline \multirow[b]{2}{*}{ No } & \multirow[b]{2}{*}{ Region } & \multicolumn{8}{|c|}{ Divisions (number of species) } \\
\hline & & 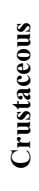 & 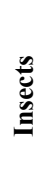 & 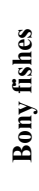 & 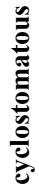 & & 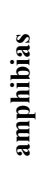 & : & $\begin{array}{l}\text { 呟 } \\
\text { İ } \\
\text { İ } \\
\text { İ }\end{array}$ \\
\hline 1 & Chechnya & 1 & 73 & 13 & 1 & 16 & 4 & 55 & 26 \\
\hline 2 & Ingushetia & 1 & 47 & 1 & - & 6 & 3 & 42 & 23 \\
\hline 3 & Dagestan & 2 & 88 & 9 & 1 & 16 & 4 & 62 & 24 \\
\hline
\end{tabular}

Ingushetia wild life is represented by 20 of fish species and subspecies, 7 kinds of amphibians, 23 kinds of creeping, more than 280 bird kinds and about 75 kinds of mammals. The Red Book of Ingushetia lists more than 40 species of invertebrate, 2 fish species, 7 reptiles' species, 55 species of birds and 23 species of mammals [9].

This list is not final. Especially invertebrates are understudied. Dagestan has 89 recorded mammal species, 350 bird species, 40 of creeping, 7 of amphibians, 134 species and subspecies of fish, about 50 thousand species of insects. The Red Book lists 90 species of invertebrates and 116 species of vertebrates [8].

Distribution of animals and plants listed in the Red Books of Chechen, Ingushetia, and Dagestan Republics on landscapes zones of North-East Caucasus evidences their dominance on the least developed nature zones - mountain-forest and mountainmeadow (Table. 4). Flora endemics here include: Veronica bogosensis, Atropa caucasica, Cladochaeta candidissima and others. The wild life includes such rare species as the Forest Cat, Persian wild goat, otter, lynx, chamois and others.

The steep zone also has a diverse flora Ophioglossum vulgatum, Centaurea pseudotanaitica Galushko, Hippophae rhamnoides) and others and fauna (owl, small tern, whitetoothed white-bellied shrew mouse, Old world water shrew by Shelkovnikov, and others). Some of them are characteristics of for mountain steeps (Astragalus fissuralis Alexeenko), tick trefoil (Hedysarum daghestanicum), oriental persimon (Diospyros lotus), Psephellus absinthifolius Galushko,
Tanacetum akinfiewii, Falco peregrines, Eremophila alpestris, Myotis blythii and others.

TABLE IV. ANIMAL AND PLANTS SPECIES LISTED IN THE RED BOOKS OF CHECHNYA, INGUSHETIA AND DAGESTAN

\begin{tabular}{|c|l|c|c|}
\hline No & \multicolumn{1}{|c|}{ Landscapes } & $\begin{array}{c}\text { Flora } \\
\text { (species } \\
\text { number) }\end{array}$ & $\begin{array}{c}\text { Fauna } \\
\text { (species } \\
\text { number) }\end{array}$ \\
\hline 1 & semi-deserts and deserts & 34 & 82 \\
\hline 2 & steeps, including mountain steeps & 94 & 132 \\
\hline 3 & inundable and deltoid & 22 & 34 \\
\hline 4 & low land sea shore growing & 30 & 49 \\
\hline 5 & forest-steeps & 48 & 108 \\
\hline 6 & mountain-forest & 149 & 105 \\
\hline 7 & mountain-meadow & 142 & 101 \\
\hline
\end{tabular}

Inundable, deltoid, and low-land sea shore landscapes have more than 50 species of plants and 100 kinds of animals which need special protection due to maximum utilization and anthropogenic impact on mountain and high-land areas. Wild life endemics of North-East Caucasus include rupicolous lizard, Caucasian grouse, field mouse prometeev, birch mouse Caucasian and others, and epibiotics include: sturgeon (hausen, Russian sturgeon, starred sturgeon), sea zander, saiga, seal and others.

In conservation of biodiversity of mountain ecosystems special nature conservation areas have a leading role (SNCA). SNCA is one of the most important ways of nature utilization aimed at protection and reproduction of biological resources, natural ecosystems revitalization for keeping ecological balance on the local and regional levels. Reserve management and studies in Russia started earlier than in other countries and the Caucasus reserve was the first (1924 г.), used in emperor Russia as imperial hunting areas [4].

North-East Caucasus regions do not have national parks, and Chechen republic does not have even reserves. According to the law of Chechen Republic "Concerning specially protected areas" (2007) with the account of specific features of protected natural territories and sites there are following protected areas: natural parks; state natural sanctuary; natural monuments; arboretums and botanic gardens.

Ingushetia has legally prescribed state natural sanctuaries (1999).

Dagestan has (1992) has besides SNCA categories described by the federal law, ecology-ethnic zones; liman complexes; natural recreational areas; natural attractions. Ecology-ethnic zones are for native ethnos. They have special mode of nature utilization for preserving natural resources, habitat and traditional life style for ethnos (article of law 25). liman complexes include land and water areas for preserving biodiversity and reproduction of rare and commercially valuable features of the animal and plant life. Among Russian regions Dagestan has high level of ethnic and cultural diversity.

SNCA system in North-East Caucasus started forming in 1963, when Chechen Republic organized hunting parks - 
Sovetskiy, Vedenskiy, and Parabochievskiy [14]. Total area of SNCA of Federal importance in regions of North-East Caucasus nowadays is 330 thousand ha, and includes two natural reserves (Dagestanian and Erzya), 7 sanctuaries and и Alpine Botanic Garden of Dagestan Scientific center RAS. Regional SNCA of North-East Caucasus are introduced with State nature sanctuaries (Bezhta, Steep, Shalinskiy, Vedenskiy, Urus-Martanovskiy, Bragunsk, Deshlagarsk and others), natural park "Verkhnii Gunib", arboretum (Groznenskiy), numerous botanic parks, hydrologic (lake Kezen Amoy, Galanchzhonsk, Shaitan-Kazak, Mochoh; mineral springs Mehlch-Hi, Ephe; waterfalls Shatioskiy, Hanadskiy, Chvakhilo), geological (oil springs: in Bolshoi Yaryk-Su valley, on the suburbs of Simsyr village), paleogeomorphological (residual mountain "Arka" and "Bratiya" along the upper course of river Gekhinka, Assatin cave) and other natural monuments [13].

SNCA area of different categories at North-East Caucasus from the creation of first sanctuaries during 1963-2006 increased nearly 7 times and was 1047899 ha (14,9\% of the total area of Dagestan, Chechnya, and Ingushetia). Reserve management and studies developed actively in 1971-1987, when most regional sanctuaries and natural parks were created (Figure. 1).

SNCA distribution in North-East Caucasus is non uniform. Most of them are situated in mountain forests, alpine and subalpine meadows and sharply decreases to the North (steeps, forest steeps, and semi-deserts). It is clearly seen in Chechnya. In Ingushetia there are no SNCA in steeps and forest steeps.

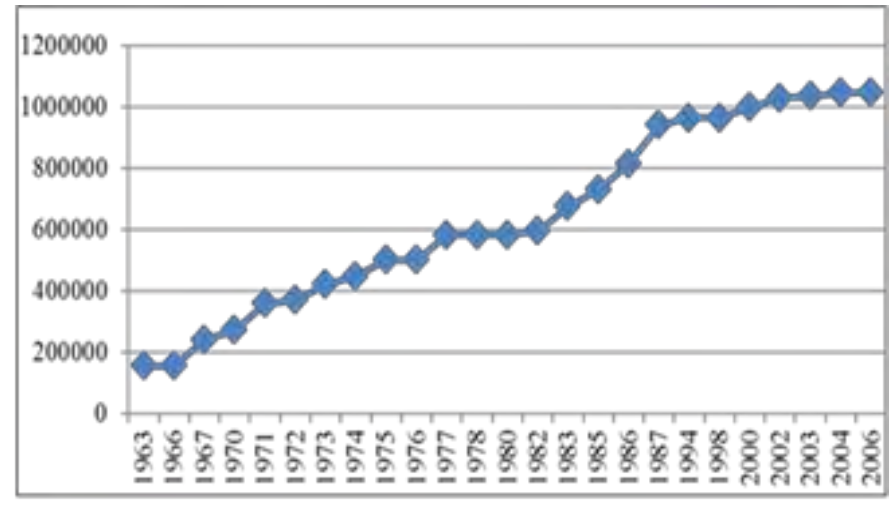

Fig. 1. SNCA area changes in North-East Caucasus during 1963-2006, ha

Chechnya and Ingushetia have 1/5 of protected area. With the account of peculiarities of mountain regions (high landscape and biological diversity, numerous historical, cultural monuments, intact nature areas), high percentage of SNCA is righteous [13].

SNCA areas in North-East Caucasus comparing with other North-Caucasus republics are not small (table 5). Except Dagestan, where they make $12.5 \%$ of the total region area (according to 01.01.2018). Water reservoirs take two thirds of the protected area. By combination of mountain, marine and costal landscapes, Dagestan differs from land of Chechnya and Ingushetia [13].
TABLE V. RELATION OF SNCA AREAS AND NUMBER IN NORTH-CAUCASUS REGIONS

\begin{tabular}{|c|l|c|c|}
\hline No & \multicolumn{1}{|c|}{ Region } & $\begin{array}{c}\text { SNCA total } \\
\text { area, ha }\end{array}$ & $\begin{array}{c}\text { \% of region } \\
\text { total area }\end{array}$ \\
\hline 1 & Chechnya & 316890 & 19.6 \\
\hline 2 & Dagestan & 628630 & 12.5 \\
\hline 3 & Ingushetia & 70012 & 19.3 \\
\hline 4 & Kabardino-Balkaria & 366100 & 29.4 \\
\hline 5 & Karachay-Cherkessia & 602400 & 42.1 \\
\hline 6 & North Osetia - Allania & 192000 & 24.0 \\
\hline
\end{tabular}

Regional SNCA efficiency in preserving biological and geo-system diversity is lower than that of federal. Contrary to existing regulating legal acts, there is no sufficient control, security management and protected areas utilization here. In Chechen Republic State Reports SNCA are not distinguished at all, but codified in other land banks.

SNCA role in providing sustainable development is hard to overestimate. But usually SNCA are introduced by isolated features and can not fulfill nature preserving functions. As F. R. Shtilmark noted three decades ago (1981), isolated protected areas can fulfill their "ecosystem, social, scientific functions" only if they make an "ecological network". To support biological balance these segregated areas should be connected with passages for animals' migration and their free dispersal. Essentially, all SNCA should be combined as spatially-linked networks (frame) of natural and semi-natural areas.

Work [14] suggests a geo-ecological network on North-East Caucasus area as a system of spatially and functionally connected highly protected areas and features. This frame should play a significant role in optimizing SNCA of NorthEast Caucasus. It is formed by basic elements (or network nucleus) which are reserves and sanctuaries, local (hydrological, botanic and other nature monuments) and linear elements (river valleys, tree belt areas along the motorways, field, forest roads and others). Linear connection of "network" nucleus is especially important for free animals' migration [14]. Its organization and practical fulfillment will support geoecological balance in this region.

Ecosystems in general and processes influencing biodiversity are not limited by state or region boundaries. It evidences insufficient nature preserving measures at the local, regional and national level. They should be coordinated on the international level in order to preserve biodiversity and natural landscapes. Creation of the ecological network on isolated natural areas and transformed landscapes supports wild life preservation and their habitat. Emerald network is an ecological network of "areas of special conservation interest". Council of Europe created it in 1989, and legally established it in 1996 with the Berne Convention [14].

By the Decree of the Executive Board of European Convention on wildlife and habitat preservation (Strasburg) on 30 November 2012, 740 features have the status of prospecting areas of Emerald Network [14]. It includes 9 specially protected natural areas and features in Chechen Republic and 13 in Dagestan Republic. As not all features intended for nature 
protected purposes at North-East Caucasus are recorded as prospective areas of Emerald Network, due to some internal reasons as basic elements of geo-ecological network the authors recommend SNCA of federal and regional significance. Recognizing the importance of indicator species, whose habitat points at good state of the territory, besides the species prioritized for common European conservation, the authors recommend the species listed in the Red Books of Russian Federation, Chechnya, Dagestan and Ingushetia.

Together with local and regional protection of ecosystems we should aim for biodiversity conservation on the global scale. Some researchers explain biodiversity reduction with insufficient financing of global diversity preservation, no stimuli for sufficient international cooperation and possibilities to manage habitat transformation on the global scale, excessive loads on natural systems and other factors [15, 19]. Global Environmental Fund has an important role in the financial support of biodiversity preservation in developing countries [16], as well as for UNESCO politics and activity in implementing international programs for biodiversity conservation and sustainable development support [21]. We should aim at global agreement on biodiversity, conceptualized by Parisian climatic agreement [20].

\section{CONCLUSION}

Biodiversity role can not be overestimated in sustainable development strategy, including practical aspects. Estimation of biodiversity allows determining weak aspects and depletion threats. Regions of North-East Caucasus are not sufficiently studied from the landscape, biogeocenotic and biological points of view. Nevertheless, these territories have high biologic diversity especially in mountainous areas, less involved in agricultural activity (in comparison with low land regions).

But the results of biological (floristic, geobotanic, faunistic) research conducted several decades ago do not reflect contemporary modern situation and should be updated systematically. According to current laws of Russian Federation, Red Books should be republished not less than one time in ten years. Consequently, in the regions of North-East Caucasus Red Books are being republished.

\section{References}

[1] A.A. Aidarliev, "Sustainable conservation of the environment in mountain regions", Sustainable development of mountain territories, no. 2, 2009, pp. 5-12.

[2] A.K. Brodskiy, N.G. Bobylev, "Biodiversity in overcoming contemporary ecological crisis: ecosystem and anthropocentric approaches research in sustainable development strategy", Saint-Petersburg University Bulletin. Earth Sciences, vol. 62, no. 3, pp. 237-253, 2017.

[3] V.V. Kovarda, "Analysis of the definition "sustainable socio-economic development”, Modern Science Success, vol. 3, no. 12, pp. 39-41, 2016.

[4] V.G. Krever, M.S. Stishov, I.A. Onufrenia, Specially protected nature conservation areas in Russia: contemporary state and perspective development. Moscow: WWF Russia, 2009, p. 456.

[5] V.N. Bolshakov, K.I. Berdugin, "Resources for sustainable development of mountain territories: global issues, Russian problems, Ural collision", Sustainable development of mountain territories, no. 2, pp. 13-26, 2009.
[6] G.V. Shlyakhtin, M.V. Yermokhin, "Value of Red Books for preservation of biological diversity and sustainable regional development (on the example of Saratov region)", Samara Luka: issues of regional and global ecology, vol. 25, pp. 83-89, 2016.

[7] Ye.A. Belonovskaya, A.A., Tishkov, "Issues of biodiversity conservation in Russia mountains (on the example of North Caucasus)", Geography studies. Mountains research. Mountain territories of northern Eurasia. Development in global changes, vol. 132. Moscow: Publishing House Kodex, pp. 107-124, 2014.

[8] Red Book of Dagestan Republic, Rare and extincting animals and plants. Makhachkala: Dagestan publishing house, 1998, p. 338.

[9] Red Book of Ingushetia Republic: Plants, Animals. Magas: Publishing House Serdalo, 2007, p. 376

[10] Red Book of Chechen Republic. Rare and extincting plants and animals. Grozniy: Southern publishing house, 2007, p. 432

[11] National conservation strategy of biodiversity in Russia. Moscow, 2002 p. 99.

[12] Our global future: UN Committee report on the environment and development. Moscow: Progress, 1989.

[13] Kh.Sh. Zaburaeva, "Bioclimatic and recreational potential of mountain territories in North-East Caucasus", Natural and Engineering Sciences, no. 1, pp. 101-106, 2018.

[14] Kh.Sh. Zaburaeva, Ye.V. Krasnov, "Emerald network of national conservation areas". Kaliningrad: Publishing house of Baltic Federal University named after I. Kant, no. 7, pp. 121-129, 2015

[15] A. Waldron, J.A. Tobias, D.S. Miller, D. Redding et al., "Reductions in global biodiversity loss predicted from conservation spending", Nature, vol. 551, no. 7680, pp. 364-367, 2017.

[16] E.B. Barbier, J.C. Burgess, T.J. Dean, "How to pay for saving biodiversity", Science, vol. 360, no. 6388, pp. 486-488, May 2018.

[17] E.J. Duffy, C.M. Godwin, B.J. Cardinale, "Biodiversity effects in the wild are common and as strong as key drivers of productivity", Nature, vol. 549, no. 7671, pp. 261-264, 2017.

[18] E. Krasnov, H. Zaburaeva, Sustainable Development and Sustainable Agriculture Russian Definitions, Sustainable Agriculture, Christine Jakobsson. Ed., 2012, pp. 60-61.

[19] H.P. Possingham, L.R. Gerber, "Ecology: The effect of conservation spending”, Nature, vol. 551, no. 7680, pp. 309-310, 2017.

[20] J. Fahrenkamp-Uppenbrink et al, "Financing biodiversity conservation", Science, vol. 360, no. 6388, pp. 503-505, 2018.

[21] M. Clüsener-Godt, A. Abreu, "UNESCO and biodiversity. Sustaining and sustainable use of biodiversity for development", Sustainable Development of Mountain Territories, vol. 7, no. 3, pp. 5-13, 2015.

[22] M. Carley, I. Christie, Managing Sustainable Development, 2nd ed., London: Earthscan, 2000, pp. 7-10.

[23] M. Mina, H. Bugmann, M. Cailleret et al. "Future ecosystem services from European mountain forests under climate change", Journal of Applied Ecology, vol. 54, no. 2, pp. 389-401, 2017.

[24] N.J. Gotelli, H. Shimadzu, M. Dornelas et. Al, "Community-level regulation of temporal trends in biodiversity", Science Advances, vol. 3, no. 7, pp. July 2017. pp. 1-8.

[25] N.G. Yoccoz, K.E. Ellingsen, T. Tveraa, "Biodiversity may wax or wane depending on metrics or taxa", Proceeding of the National Academy of Sciences of the United State of America, vol. 115, no. 8, pp. 1681-1683, February 2018.

[26] S.N. Bobylev, E.N. Bukvareva, A.A. Danilkin et al. Ecosystem services of Russia: Prototype National Repor. Moscow: BBC Press, vol. 1, 2018, p. 115.

[27] T. Newbold, L.N. Hudson, A.P. Arnell et al., "Has land use pushed terrestrial biodiversity beyond the planetary boundary? A global assessment”, Science, vol. 353, no. 6296, pp. 288-291, July 2016.

[28] Y. Hautier, D. Tilman, F. Isbell et al. "Anthropogenic environmental changes affect ecosystem stability via biodiversity", Science, vol. 348, no. 6232, pp. 336-340, April 2015. 